\title{
PEMAHAMAN GURU TERHADAP KONSEP PENDIDIKAN KARAKTER DI SMP KABUPATEN MUSI BANYUASIN
}

\author{
${ }^{1}$ Yustriani \& ${ }^{2}$ Yusnarni \\ ${ }^{1}$ SMP Negeri 2 Babat Supat ${ }^{2}$ SMA Negeri 1 Betung \\ e-mail: 1 yustrianiyus@gmail.com²yusnarni8@gmail.com
}

\begin{abstract}
Character education in SMP Negeri 2 Babat Supat has already been integrated in the curriculum in every subject, but on the other hand the teachers' understanding and mastery of the concept of character education needs to be reviewed further, the teachers did not understand the nature of the concept of character education. The content of character values found in learning during the learning activities include: 1) Religious, 2) Honest, 3) Tolerance, 4) Discipline, 5) Hard work, 6) Creative, 7) Independent, 8) Democratic , 9) The Want to Know, 10) The Spirit of Nationality, 11) The Love of the Homeland, 12) Respect for Achievement, 13) Friendly / Communicative, 14) Peaceful Love, 15) Love Reading, 16) Environmental Care, 17) Social Care, and 18) Responsibility. This qualitative research investigate the understanding of teachers to the concept of character education. Lack of deep understanding of a teacher on the concept of character education will inhibit the implemention to the learners, so it needs to be held again coaching or training of teachers and employees in SMP Negeri 2 Babat Supat.
\end{abstract}

Keywords: Deep Understanding of a Teacher; Concept of Character Education; SMP Negeri 2 Babat Supat.

PENDAHULUAN

Perkembangan prilaku masyarakat dalam berbagai aspek kehidupan sangatlah menghawatirkan bagi kemajuan perkembangan pembanguanan negari yang kita cintai ini. Kompas memberitakan bahwa berdasarkan indeks persepsi korupsi, yang dilaksanakan oleh lembaga survey Transparency Internasional, Indonesia masih masuk jajaran Negara-negara terkorup dengan menempati peringkat ke-118 dari 174 negara (Kompas, 2012). Masih dengan harian yang sama, Badan Kehormatan DPR melaporkan ada 28 anggota dewan tersangkut masalah etika. Kondisi di atas diperburuk dengan krisis moral dan budi pekerti para pemimpin bangsa yang berimbas pada generasi muda. Tawuran Antara pelajar, perilaku seks bebas, penyalahgunaan narkoba, budaya tak tahu malu, tata nilai dan norma yang semakin merosot tidak hanya di perkotaan tapi sudah merambah ke pedesaan (Zuriah, 2007). Sebagai solusi pendidikan diharapkan dapat mengurangi penyebab dari berbagai masalah budaya dan karakter bangsa. Upaya perbaikan kondisi tersebut maka diperlukan pemahaman dan langkah membangun kembali karakter bangsa sesuai nilai-nilai Pancasila. Penyelenggaraan pendidikan karakter menjadi satu hal yang multlak dilakukan di jenjang pendidikan manapun. Hal ini sangat beralasan karena pendidikan adalah pondasi utama bagi tumbuh kembang 
generasi muda Indonesia (Wulandari \& Kristiawan, 2017).

Kurikulum bukan merupakan patokan yang baku dan statis, tetapi sangat dinamis dan menyesuaikan dengan situasi dan kondisi yang ada (Marzuki, 2012). Dalam kurun waktu terakhir dunia pendidikan mengalami beberapa perubahan kurikulum. Kurikulum kita selama ini masih terfokus pada kemampuan kecerdasan intelektual saja. Hal ini mengakibatkan tidak sedikit siswa yang mengalami kesulitan dalam menghadapi beban belajar, sehingga banyak di antara mereka berbelok arah melakukan kegiatan-kegiatan yang menyimpang, there are still many students who cheat on exams when on, being lazy, conflict between fellow students, doing promiscuity, drugs, and others (Kristiawan, 2015). Fenomena ini mengharuskan para praktisi pendidikan untuk membuat kurikulum pendidikan yang memiliki nilai budaya dan karakter bangsa. Nilai-nilai pendidikan karakter yaitu yang bersumber dari agama, Pancasila, budaya, dan tujuan pendidikan nasional, yaitu: 1) Religius, 2) Jujur, 3) Toleransi, 4) Disiplin, 5) Kerja keras, 6) Kreatif, 7) Mandiri, 8) Demokratis, 9) Rasa Ingin Tahu, 10) Semangat Kebangsaan, 11) Cinta Tanah Air, 12) Menghargai Prestasi, 13) Bersahabat/ Komunikatif, 14) Cinta Damai, 15) Gemar Membaca, 16) Peduli Lingkungan, 17)
Peduli Sosial, dan 18) Tanggung Jawab (Puskurbuk, 2011: 3).

Beranjak dari keadaan di atas, maka artikel ini akan membahas faktor-faktor yang menunjang terlaksananya pendidikan yang menciptakan insan-insan yang berkarakter. SMP Negeri 2 Babat Supat merupakan lembaga pendidikan yang mempunyai visi: Sekolah Yang Berprestasi, Bertaqwa dan Berwawasan Lingkungan dan mempunyai misi: 1) Berprestasi dalam bidang akademik dan non akademik, 2) Menumbuhkan etos kerja yang tinggi untuk mencapai guru yang professional, 3) Menghasilkan siswa yang berakhlak mulia, berbudi pekerti, sopan santun dan senantiasa beriman, 4) Membiasakan Guru, Pegawai dan Siswa untuk selalu hidup bersih pada diri sendiri dan lingkungan sekolah.

SMP Negeri 2 Babat Supat merupakan lembaga pendidikan yang berorientasi pada terwujudnya lulusan yang memiliki karakter sehingga setiap siswa mampu melanjutkan pendidikan sesuai dengan bakat dan kepribadian yang dimiliki. Penyelenggaraan pendidikan karakter menjadi satu hal yang mutlak dilakukan di jenjang pendidikan manapun, khususnya di jenjang pendidikan tingkat SMP. Hal ini beralasan karena pada tingkat SMP inilah siswa harus mulai menentukan kearah mana tujuan hidupnya kelak, mau kemana mereka melanjutkan pendidikan yang sesuai dengan 
keinginan atau cita-citanya. Menurut temuan Ahmad dkk (2017) Pembelajaran Karakter dapat membudayakan sopan santun dalam hubungan antarwarga sekolah sehingga timbul keakraban dan kekeluargaan yang harmonis dan menumbuhkan penghayatan dan pengamalan ajaran agama yang dianut dan juga budaya bangsa sehingga menjadi sumber kearifan dalam bertindak.

Namun yang terjadi masih banyak guru yang kurang paham terhadap konsep Pendidikan karakter. Kurangnya pemahaman yang mendalam dari seorang guru terhadap konsep pendidikan karakter yang akan diimplementasikan kepada peserta didik. Bagaimana peserta didik mampu memahami dan melaksanakan pengembangan karakter jika tenaga pendidik sendiri belum memahami konsep karakter itu sendiri. Tugas-tugas pendidik adalah menyediakan lingkungan belajar yang baik untuk membentuk, mengembangkan dan memantapkan karakter peserta didiknya (Kristiawan, 2016).

Meskipun pendidikan karakter di wilayah Kabupaten Musi Banyuasin sudah mulai diintegrasikan dalam kurikulum dihampir semua jenjang pendidikan, namun di sisi lain pemahaman dan penguasaan guru terhadap konsep pendidkan karakter harus ada tindak lanjutnya. Dalam penelitian ini yang dimaksudkan adalah mengidentifikasi pemahaman dan penguasaan guru SMP
Negeri 2 Babat Supat Kabupaten Musi Banyuasin.

\section{METODE PENELITIAN}

Peneliti melakukan penelitian dengan menggunakan pendekatan kualitatif. Menurut Kristiawan \& Tobari (2017) pendekatan kualitatif merupakan descriptive; concerned with process rather than simply with outcomes or product; qualitative research tend the analyze their data inductively; and "meaning" is the essential concern to the qualitative approach.

Pendekatan kualitatif adalah suatu pendekatan dalam melakukan penelitian yang beroriantasi pada gejala-gejala yang bersifat alamiah karena orientasinya demikian, maka sifatnya naturalistik dan mendasar atau bersifat kealamiahan serta tidak bisa dilakukan di laboratorium melainkan harus terjun di lapangan (Nazir Muhammad, 1988).

Dalam pendekatan kualitatif, peneliti memaparkan suatu gambaran yang terinci dari responden langsung, dan melakukan studi pada situasi yang alami, data yang didapat berupa kata-kata dan kalimat (data deskriptif) untuk menjabarkan hasil penelitian. Dilanjutkan dengan melakukan analisi dari data yang di temukan.

Data yang diambil dari sekolah yang diteliti adalah SMP Negeri 2 Babat Supat 
yang terfokus pada guru-gurunya. Melalui wawancara peneliti mengumpulkan data berkaitan dengan pemahaman guru terhadap konsep pendidikan karakteristik. Selanjutnya melakukan observasi langsung dengan mengamati kegiatan proses belajar maupun di luar proses belajar mengajar. Kemudian data yang telah didapat dikumpulkan dan dianalisis melalui tiga tahapan kegiatan secara bersamaan yaitu: reduksi data, penyajian data dan penarikan kesimpulan/ verifikasi (Milles dan Huberman, 1992).

\section{HASIL PENELITIAN DAN PEMBAHASAN}

Guru merupakan salah satu factor penentu dalam keberhasilan pelaksanaan pendidikan karakter di sekolah sehingga diperlukan pemahaman yang baik tentang konsep dari pendidikan karakter. Sesuai hasil wawancara dan observasi terhadap sejumlah guru di SMP Negeri 2 Babat Supat diketahui bahwa hakikat pendidikan karakter belum dipahami oleh semua guru di sekolah. Menurut mereka pendidikan karakter yaitu proses pembentukan sikap siswa. Berdasarkan kenyataan itu Guru belumlah spenuhnya mengembangkan nilai-nilai karakter kepada peserta didiknya dalam proses kegiatan belajar mengajar dikelas. Seharusnya salah satu strategi pengembangan pendidikan karakter adalah dengan mengintegrasikan nilai-nilai karakter bangsa pada setiap mata pelajaran sehingga menghasilkan peserta didik yang konsisten dalam perilaku berkarakter dikehidupannya sehari-hari.

Pendidikan karakter merupakan bentuk kegiatan manusia yang di dalamnya terdapat suatu tindakan yang mendidik dan diperuntukkan bagi generasi selanjutnya. Tujuan pendidikan karakter adalah untuk membentuk penyempurnaan diri individu secara terus-menerus dan melatih kemampuan diri demi menuju ke arah hidup yang lebih baik (Kusuma, 2007). Renata dkk (2017) menyebutkan bahwa pendidikan karakter adalah suatu sistem penanaman nilai-nilai karakter kepada warga sekolah yang meliputi komponen pengetahuan, kesadaran atau kemauan, dan tindakan untuk melaksanakan nilai-nilai tersebut.

Pendidikan karakter seharusnya membawa peserta didik kepada penilaian secara kognitif, penghayatan nilai secara afektif, dan akhirnya ke pengalaman nilai secara nyata. Inilah rangcangan pendidikan karakter (moral) oleh Lickona (1991) di sebut moral knowing, moral feeling, dan moral action. Karena itulah, semua mata pelajaran yang dipelajari oleh peserta didik di sekolah harus bermuatan pendidikan karakter yang bisa membawanya menjadi manusia yang berkarakter seperti yang ditegaskan oleh Lickona tersebut.

Sesuai dengan hal di atas pendidikan karakter dapat dikembangkan dengan cara 
latihan terus menerus, kita sebagai pendidikan seharusnya tanpa bosan dan lelah untuk mengingatkan kepada peserta didik untuk memahaminya dan melaksanakan semua itu secara teratur dan fleksibel sehingga nantinya akan mendapatkan hasil yang diharapkan sesuai dengan tujuan pendidikan karakter.

Pemahaman guru di sekolah tentang pendidikan karakter menjadi faktor utama dalam mewujudkan tujuan dari pendidikan karakter dan guru juga harus mampu memberikan contoh dari hal-hal yang berkaitan dengan pendidikan karakter, peneliti sendiri secara langsung mendapatkan informasi bahwa masih ada guru yang beranggapan bahwa masih ada guru yang beranggapan bahwa karakter hanya dapat dikembangkan melalui pengintegrasian dalam mata pelajaran dan pelatihan-pelatihan sikap tanpa adanya peneladanan atau pemberian contoh dari guru mengenai sikap yang berkaitan dengan pendidikan karakter. Dari hal tersebut menyebabkan pendidikan karakter di SMP Negeri 2 Babat Supat belum dapat berkembang dengan baik. Sehingga kita sebagai pihak sekolah maupun pendidik harus dapat menciptakan kondisi sekolah yang sesuai dengan nilai-nilai karakter bangsa.

Untuk menghasilkan (output) peserta didik yang mampu memehami nilai yang benar dan salah (kognitif), merasakan nilai yang baik dan buruk (afektif), serta terbiasa untuk selalu berperilaku yang baik (psikomotorik) (Puskurbuk, 2011). Perkembangan seorang anak adalah mengembangkan pemahaman yang benar tentang bagaimana dunia ini bekerja, mempelajari "aturan main" segala aspek yang ada di dunia ini. Anak-anak akan tumbuh menjadi pribadi yang berkarakter apabila dapat tumbuh pada lingkungan yang berkarakter (Wibowo, 2011).

Dari hal-hal di atas kontribusi pembiasaan dan pencontohan sikap merupakan strategi yang tepat dalam menanamkan dan membentuk sikap peserta didik yang berkarakter. Pendiikan karakter merupakan salah satu upaya yang harus di laksanakan sekolah untuk membina moral serta akhlak yang sesuai dengan norma dan nilai-nilai dari Tuhan Yang Maha Esa, dan dilaksanakan sebagai bentuk penempaan terhadap sikap peserta didik sebagai anak bangsa yang tangguh serta mampu berkompetensi sehat pada zamannya.

Nilai-nilai pendidikan karakter yaitu yang bersumber dari agama, Pancasila, budaya, dan tujuan pendidikan nasional, yaitu: (1) Religius, (2) Jujur, (3) Toleransi, (4) Disiplin, (5) Kerja keras, (6) Kreatif, (7) Mandiri, (8)Demokratis, (9) Rasa Ingin Tahu, (10) Semangat Kebangsaan, (11) Cinta Tanah Air, (12) Menghargai Prestasi, 
(13) Bersahabat/ Komunikatif, (14) Cinta Damai, (15) Gemar Membaca, (16) Peduli Lingkungan, (17) Peduli Sosial, \& (18) Tanggung Jawab (Puskurbuk, 2011: 3). Nilai-nilai ini merupakan target pencapaian yang diharapkan dan mulai di laksanakan di SMP Negeri 2 Babat Supat, walaupun guru sebagai factor utama belum maksimal melaksanakannya dan guru sendiri masih banyak yang kurang memahami konsep pendidikan karakter. Tetapi Kepala Sekolah terus berusaha mengajak guru dan pegawai untuk sedikit demi sedikit menerapkan pendidikan karakter kepada pesrta didik.

Nilai karakter yang mulai dikembangkan melalui pembiasaan sikap di sekolah yaitu: 1) Melaksanakan upacara bendera setiap hari senin, serta menyanyikan lagu-lagu nasional sebagai implementasi nilai semangat kebangsaan,

Melaksanakan apel setiap pagi hari untuk berdoa berdoa bersama memulai pelajaran dan mengakhiri pelaran dengan doa bersama juga serta meminta izin keluar/masuk kelas sebagai implementasi nilai religius, 3) Melaksanakan tugas piket kebersihan kelas, menanami/merawat tanaman yang ada di sekitar kelas sebagai implementasi nilai peduli lingkunga, 4) Membaca Yassin bersama setiap hari Jumat.

Selain pembiasaan sikap, ada beberapa guru yang mulai mengintegrasikan nilai pendidikan karakter dalam kegiatan pembelajaran di kelas yaitu dengan menggunakan metode pembelajaran diskusi sebagai nilai komuniktif/bersahabat. Selain itu, ada juga pemberian tugas yang kepada peserta didik ketika guru tidak masuk memberikan pembelajaran di kelas sehingga siswa sudah terbiasa untuk belajar di kelas meski tidak ada guru, hal tersebut mencerminkan nilai mandiri.

Di sekolah juga mulai ada pengkondisian meskipun pelaksanaannya belum sesuai dengan indikator nilai karakter bangsa yang ada. Pengkondisian yang dilaksanakan di sekolah seperti: Menyediakan tempat pembuangan sampah organik dan anorganik di setiap kelas, serta mengunjungi teman yang sakit, dan menyediakan buku ramadhan untuk peserta didik, serta merayakan hari-hari besar keagamaan dengan berdzikir bersama di Masjid dekat sekolah. Kegiatan spontan juga dilaksanakan di sekolah oleh guru dan peserta didik yaitu guru langsung menegur peserta didik saat melakukan kesalahan.

Pelaksanaan kegiatan di atas tidak akan berhasil jika guru belum memahami konsep pendidikan karakter dan tanpa dilaksanakan secara kontiyu. Hasil yang di dapat di SMP Negeri 2 Babat Supat belum maksimal, hal ini dapat dilihat dari beberapa siswa yang belum membuang sampai pada tempatnya, peserta didik yang belum memiliki disiplin, masih sering terlambat 
masuk kelas, baris di lapangan, tidak memakai seragam sekolah yang ada dalam aturan di sekolah.

Hal-hal di atas menunjukkan belum tercapainya indikator keberhasilan yang di capai, masih banyak yang harus di perbaiki misalnya dari peraturan-peraturan tata tertib peserta didik yang harus lebih tegas dengan sanksi-sanksi yang di berikan haruslah bisa membuat pelaku jera tidak akan mengulangi perbuatan-perbuatan yang melanggar aturan yang ada, dan terutama sekali guru sebagai pelaku utama dalam pembentukan karakter peserta didik harus memahami konsep pendidikan karakter. Kepala Sekolah harus terus meningkatkan pembinaannya baik kepada guru mapun kepada peserta didik.

\section{KESIMPULAN}

Dalam penelitian ini penulis menemukan bahwa masih ada guru yang belum memahami konsep dari pendidikan karakter bangsa yang harus dimiliki peserta didik di SMP Negeri 2 Babat Supat. Pemahaman guru di sekolah tentang pendidikan karakter menjadi faktor utama dalam mewujudkan tujuan dari pendidikan karakter dan guru juga harus mampu memberikan contoh dari hal-hal yang berkaitan dengan pendidikan karakter. Oleh karena itu pengetahuan guru tentang konsep pendidikan karakter harus ditingkatkan.

\section{DAFTAR PUSTAKA}

Ahmad, S., Kristiawan, M., Tobari, T., \& Suhono, S. (2017). Desain Pembelajaran SMA Plus Negeri 2 Banyuasin III Berbasis Karakter Di Era Masyarakat Ekonomi ASEAN. Iqra (Educational Journal), 2(2), 403432.

Asmani, Jamal Ma'mur (2011). Buku Panduan Internalisasi Pendidikan Karakter diSekolah. Jogjakarta: DIVA Press.

Albertus, D.K (2007). Pendidikan Karakter: Strategi Mendidik Anak di Zaman Global.Jakarta: Grasindo.

Kristiawan, M. (2015). A Model of Educational Character in High School Al-Istiqamah Simpang Empat, West Pasaman, West Sumatera. Research Journal of Education, 1(2), 15-20.

Kristiawan, M. (2016). Telaah Revolusi Mental Dan Pendidikan Karakter Dalam Pembentukan Sumber Daya Manusia Indonesia Yang Pandai Dan Berakhlak Mulia.

Kristiawan, M. (2017). The Characteristics of the Full Day School Based Elementary School. Transylvanian Review, 1(1).

Nazir Muhammad. (1988) Metode Penelitian, Bandung: Remaja Rosdakarya.

Renata, R., Kristiawan, M., \& Pratami, F. A. R. (2017, December). Perbincangan Pendidikan Karakter. In Prosiding Seminar Nasional Program Pascasarjana.

Sulhan, Najib. 2011. Pendidikan Berbasis Karakter. Surabaya: PT Jepe Pres MediaUtama (Jawa Pos Grup). 
Wibowo, T. 2011. Kurikulum Pendidikan Karakter, (Online). (http:timothywibowoartikel-pendidikankarakter.com, diakses 16 Desember 2011).
Wulandari, Y., \& Kristiawan, M. (2017). Strategi Sekolah dalam Penguatan Pendidikan Karakter Bagi Siswa dengan Memaksimalkan Peran Orang Tua.JMKSP (Jurnal Manajemen, Kepemimpinan, dan Supervisi Pendidikan), 2(2). 